\title{
A Review on Phytochemical Studies and Biological Potential of Citrullus colocynthis (L.) Schrad. (Cucurbitaceae)
}

\author{
Prashant Kumar Dhakad ${ }^{1, *}$, Pramod Kumar Sharma ${ }^{1}$, Sokindra Kumar ${ }^{2}$ \\ ${ }^{1}$ Department of Pharmacy, Galgotias University, India \\ ${ }^{2}$ R.V. Northland Institute (RVNI), Chithera, Dadri, Greater Noida-II, India
}

Copyright $@ 2017$ by authors, all rights reserved. Authors agree that this article remains permanently open access under the terms of the Creative Commons Attribution License 4.0 International License

\begin{abstract}
Cucurbits are edible crops found in the Cucurbitaceae family. Interest in plant-based biological compounds has now awakened throughout the world and hence the literature data in this area is significant. The Cucurbitaceae family is distributed in the tropical and subtropical countries. The plants of this family are superb fruit crops rich in vitamins, nutrients, and minerals that very good for health. A number of plants belonging to this family have been reported so far and one among them is Citrullus colocynthis (L.) Schrad. All the parts of this plant (root, stem, leaf, fruits, and seeds) are utilized in the traditional system of medicine. A plethora of research is going on this plant species to discover new active moiety and to establish their medicinal importance. The present review gives updated information about the phytochemistry and pharmacological activities of Citrullus colocynthis (L.) Schrad. established so far. As per the research so far among different cucurbitacins, cucurbitacin $\mathrm{E}$ is known to be found profoundly in Citrullus colocynthis (L.) Schrad. Some of the biological activities reported for this plant include antioxidant activity, antimicrobial activity, anti-diabetic activity, anti-hyperlipidemic activity, analgesic activity, anti-ulcer activity, anticonvulsant activity and insecticidal activity.
\end{abstract}

Keywords Cucurbitaceae Family, Citrullus colocynthis, Traditional System, Phytochemistry, Biological Activities

\section{Introduction}

Cucurbitaceae family is one of the best genetically assorted accumulations of restorative plants in the plant kingdom. Most plants of this family are dry season tolerant, intolerant to wet, frost-sensitive and ineffectively drained soils [1]. In the course of the most recent two decades,
India and China have been the biggest cucurbit makers took after by Russia, United States of America, Egypt and Republic of Iran. Citrulluscolocynthis (L.) Schrad. is a Cucurbitaceae family plant[1]. The plant is generally accessible in the Sahara and Arabian deserts, Sudan and a Southern piece of Asia including Pakistan, India and Southern Islands. The fruit is intense and globular with a smooth surface. It is hard and has a skin around it and contains 200-300 seeds/gourd. Seeds are small (6mm in length), ovoid, compressed, smooth and brownish when ripe. Seeds constitute about $75 \%$ of the weight of fruit of Citrullus colocynthis [2]. It is a non-tough, herbaceous lasting vine, extended from the base. The stems are precise and harsh; the leaves rough, 2-4 inches long, with 3-7 profound lobes; and solitary light yellow blossoms are found. Each plant generates 15-30 round fruits, with 3-4inches in diameter, green with undulate yellow stripes, getting to be noticeably yellow all finished when dry. Seeds are 1/4 inch or less long, smooth and caramel when riped [3]. In the Vedic literature, it is mentioned that "There is no man on this planet that is inept and there is no plant which has no medical use. Where everything is available, actually, a man to oversee them legitimately is rarely accessible [4]. Practically speaking, a plant is called restorative plant, when it is very used in the system of medicine [4]. Nowadays, therapeutic plants get attention to researchers because of their special significance in safety of humanity. The curative properties of therapeutic plants are predominantly because of the presence of different chemical constituents of various compositions which exists as secondary metabolites. A few dynamic synthetic constituents of C. colocynthis plant were surveyed. They are grouped as saponins, carbohydrates, tannins, glycosides, alkaloids, flavonoids and essential oils. Plant-based characteristic constituents can be obtained from any part of the plant like leaves, roots, flowers, stems, fruits, and seeds. Various plant secondary metabolites 
including flavonoids and cucurbitacins have already been accounted for from C. colocynthis [5]. Citrullus colocynthis (L.) Schrad. has a wide range of therapeutic and nutritional uses. Traditionally this plant is used in the treatment of diseases like cancer, leucoderma, ulcers, asthma, bronchitis, urinary discharge, enlargement of spleen, tuberculosis glands of the neck, dyspepsia, constipation, anemia and throat diseases.

The data of phytochemical studies and biological activities of Citrullus colocynthis (L.) Schrad. plant parts were collected through authenticated sources like Google Scholar, PubMed, ScienceDirect etc.

\section{Phytochemical Studies}

A few bioactive compounds of Citrullus colocynthis (L.) Schrad. fruit have been elucidated in the studies so far. They are included as carbohydrates, alkaloids, fatty acids, glycosides, flavonoids and essential oils. The cucurbitacins are prevalently found in the Cucurbitaceae family. As per chemical structures, cucurbitacins can be divided into 12 categories, yet all are not found in Citrullus colocynthis (L.) Schrad. Because of the cytotoxic conduct, cucurbitacins seem to assume an important part in medicate disclosure, especially in anticancer medication advancement. Among different cucurbitacins, cucurbitacin E (compound a) was discovered richly in Citrulluscolocynthis (L.) Schrad. fruit pulp. Colocynthoside A (compound b) and colocynthoside $B$ (compound $\mathrm{c}$ ), were isolated from the methanolic concentrate of the fruits. Different cucurbitacins secluded from the butanol part were, cucurbitacin L 2-O- $\beta$-D-glucopyranoside (compound d), hexanocucurbitacin I 2-O- $\beta$-D glucopyranoside (compound e), cucurbitacin K 2-O- $\beta$-D glucopyranoside (compound $\mathrm{f}$ ) and khekadaengoside $\mathrm{E}$ (compound g), cucurbitacin J 2-O- $\beta$-D glucopyranoside (compound h), cucurbitacin I 2-O- $\beta$-D glucopyranoside (compound i). Some flavonoid glycosides e.g., isoorientin 30-O-methyl ether (compound j), isovitexin (compound $\mathrm{k}$ ) \&isosaponarin (compound l)and two cucurbitacin glycosides e.g. 2-O- $\beta$-D-glucopyranosyl cucurbitacin L \& 2-O- $\beta$-D-glucopyranosyl cucurbitacin I were also identified in butanol fraction of the methanolic extract of Citrullus colocynthis (L.)Schrad. fruits. The major fatty acids found in Citrullus colocynthis (L.) Schrad. seed oil includes palmitic (8.1-17.3\%) and stearic acids (6.1$10.5 \%$ ) that form principal saturated fatty acids of this oil Linoleic and oleic acids are the primary monounsaturated fats, and this high content of linoleic acid (50.6-60.1\%) in seed oil, which is an essential unsaturated fat, makes this oil restoratively profitable. The unsaturated fat profile of the seed oil uncovers that it falls in the class of linoleic-oleic acid oils and closely resembles a few other vegetable oils. In this way, the Citrullus colocynthis (L.) Schrad. oil, similar to some other cucurbit seed oils, is probably going to have potential uses as a cooking oil. Previous studies reported that the seed oil composition of this plant was like that of safflower oil, with an aggregate of $80-85 \%$ unsaturated fats. An investigation detailing the physical-compound portrayal and the fatty acid composition of the fixed oil of the seeds revealed that it is a decent wellspring of characteristic cancer prevention agents like uncovered that it is a decent wellspring of characteristic cancer prevention agents like natural antioxidants e.g., $\alpha$-tocopherol, $\gamma$-tocopherol and $\beta$-carotene with respective composition of 45.1, 435 and $0.18 \mathrm{mg} / \mathrm{kg}$. Many examinations revealed the presence of alkaloids in the Citrullus coloccynthis fruits however just a couple of reports are accessible on the isolation and identification of individual alkaloids. A study was done in 1973 in which choline and two unidentified alkaloids from fruit pulp of Citrullus colocynthis (L.) Schrad was isolated. Citrullus colocynthis (L.) Schrad. is a superb wellspring of various amino acids as methionine, arginine, and tryptophan. The biological files its protein quality has been depicted as: "lower than soybean however similar to or higher than generally oilseeds." Citrullus colocynthis (L.) Schrad. fruits and seeds possess many vitamins and minerals that play an important role in the diet. The potential of Citrullus colocynthis (L.) Schrad. seed as a source of calcium and niacin is encouraging to the low milk-consuming zones of the world. Citrullus colocynthis (L.) Schrad. seeds contain ash-2.00g/100g, protein$13.19 \mathrm{~g} / 100 \mathrm{~g}$, moisture- $4.91 \mathrm{~g} / 100 \mathrm{~g}$, fat-18.59 g/100 g and mineral such as Calcium- $569 \mathrm{mg} / 100 \mathrm{~g}$, Potassium$465 \mathrm{mg} / 100 \mathrm{~g}$, Magnesium- $210 \mathrm{mg} / 100 \mathrm{~g}$, Phosphorous $30.0 \mathrm{mg} / 100 \mathrm{~g}$, Sodium- $11.9 \mathrm{mg} / 100 \mathrm{~g}$, Iron- $11.6 \mathrm{mg} / 100$, Copper- $5.1 \mathrm{mg} / 100 \mathrm{~g} \&$ Zinc- $1.1 \mathrm{mg} / 100 \mathrm{~g}$.[2] The details of chemical constituents elucidated till now have been described in Table No. 1 and Figure 1. 
Table 1. Representation of different chemical constituents found in various plant parts extracts of Citrullus colocynthis (L.)Schrad

\begin{tabular}{|c|c|c|c|c|}
\hline S. No & Plant Part & Extract & Chemical constituent & References \\
\hline 1. & Fruit & Methanolic extract & Ursolic Acid and Cucurbitacin E 2-O- $\beta$-D-glucopyranoside & [6] \\
\hline 2. & leaf & $\begin{array}{l}\text { Ethyl acetate extract of } \\
\text { Citrullus colocynthis } \\
\text { (L.)Schrad. leaves } \\
\end{array}$ & $\begin{array}{c}\text { 25-p-coumaroyl-3'- acetyl-2-O- } \beta \text {-D- glucocucurbitacin I \& } \\
\text { 6'-acetyl-2-O- } \beta \text {-D-gluco-cucurbitacin }\end{array}$ & [7] \\
\hline 3. & $\begin{array}{l}\text { Whole } \\
\text { plant }\end{array}$ & Methanolic extract & $\begin{array}{c}\text { colocynthins A, B \& C along with } \beta \text {-sitosterol, } \\
\text { 3-O- } \beta \text {-D-glucopyranoside, elaterinide, and bryoamaride }\end{array}$ & [8] \\
\hline 4. & Fruit & Methanol extract & 4-methylquinoline & [9] \\
\hline 5. & $\begin{array}{l}\text { Leaf, stem, } \\
\text { fruit, and } \\
\text { root }\end{array}$ & $\begin{array}{l}\text { Soxhlet extracted in } 80 \% \\
\text { methanol and then } \\
\text { re-extracted with petroleum } \\
\text { ether, diethyl ether, and ethyl } \\
\text { acetate }\end{array}$ & Quercetin & [10] \\
\hline 6. & Fruits & $\begin{array}{l}\text { Butanol fraction of the } \\
\text { hydro-methanolic (70\%) } \\
\text { extract of the fruits }\end{array}$ & $\begin{array}{c}\text { 3'-O-methyl ether and two cucurbitacin glycosides, } \\
\text { 2-O- } \beta \text {-D-glucopyranosyl-cucurbitacin L \& } \\
\text { 2-O- } \beta \text {-D-gluco-pyranosyl-cucurbitacin }\end{array}$ & [11] \\
\hline 7. & $\begin{array}{l}\text { Whole } \\
\text { plant }\end{array}$ & Chloroform extract & $\begin{array}{l}\text { 2-O- } \beta \text {-D-glucopyranosyl-cucurbitacin E, } \\
\text { 2-O- } \beta \text {-D-glucopyranosyl-cucurbitacin I, 2-O- } \beta \text {-D- } \\
\text { glucopyranosyl-cucurbitacin L and 2-O- } \\
\beta \text {-D-glucopyranosyl-(22 -27)-hexanor-cucurbitacin I }\end{array}$ & [12] \\
\hline 8. & Fruits & Ether extract & $\begin{array}{l}\text { elatericin B (II) (cucurbitacin I) dihydroelatericin B (III) and } \\
\text { tetrahydroelatericin B (IV), elaterinidell }\end{array}$ & [13] \\
\hline 9. & Fruits & $\begin{array}{c}\text { Chloroform: } \\
\text { Methanol(1:1)ratio }\end{array}$ & cucurbitacin E and cucurbitacin I glycosides & [14] \\
\hline 10. & Fruits & Butanol extract & 2-O-D-glucopyranosyl-cucurbitacin E & [15] \\
\hline 11. & Fruits & Fruit extract & 2-O- $\beta$-D- glucopyranosylcucurbitacins I, J, K, and L & [16] \\
\hline
\end{tabular}

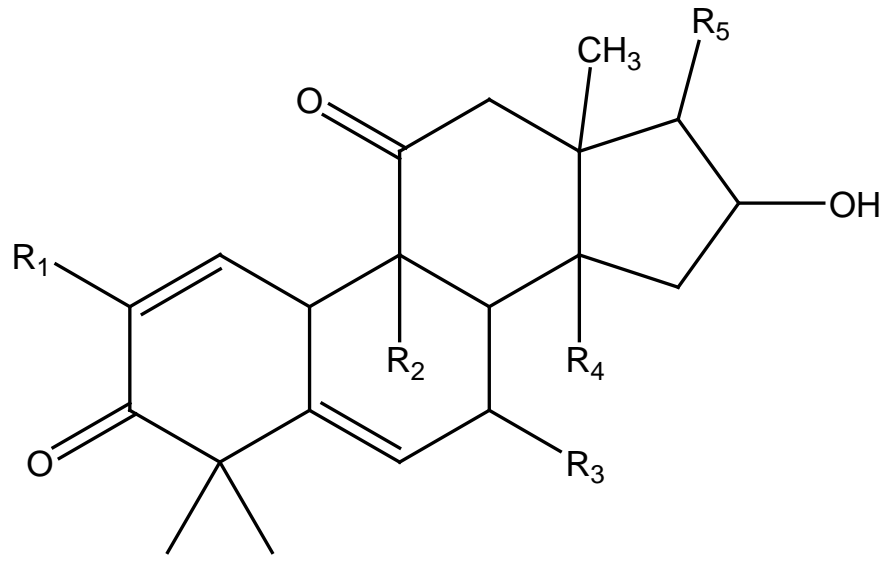

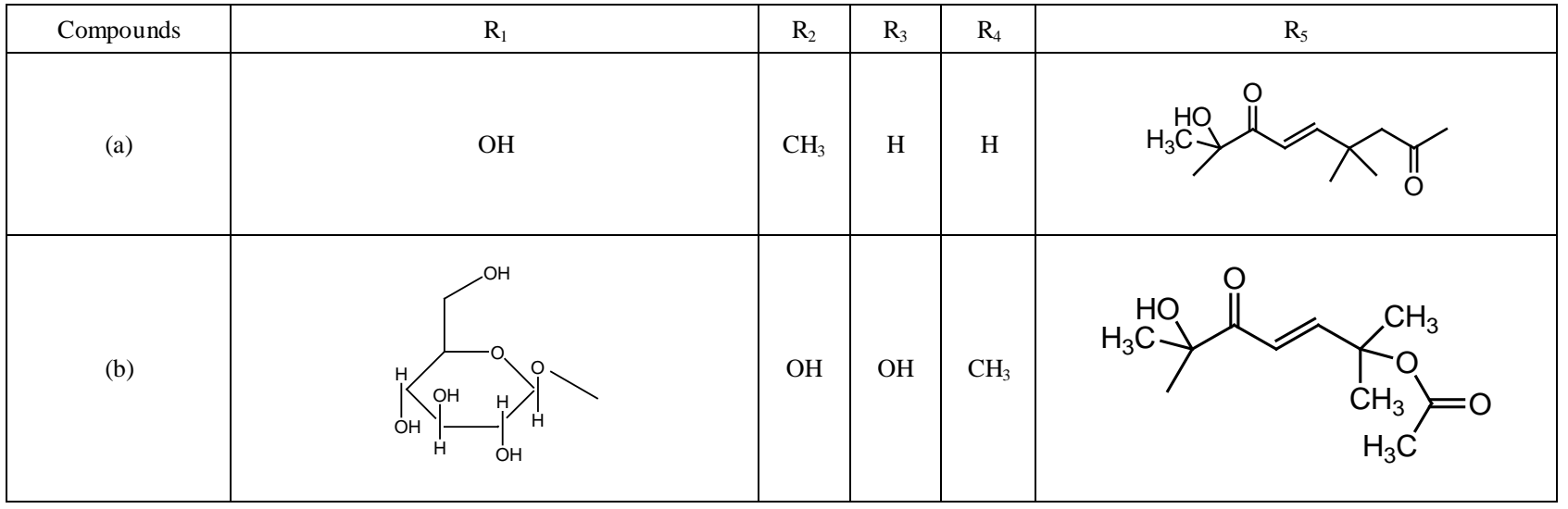




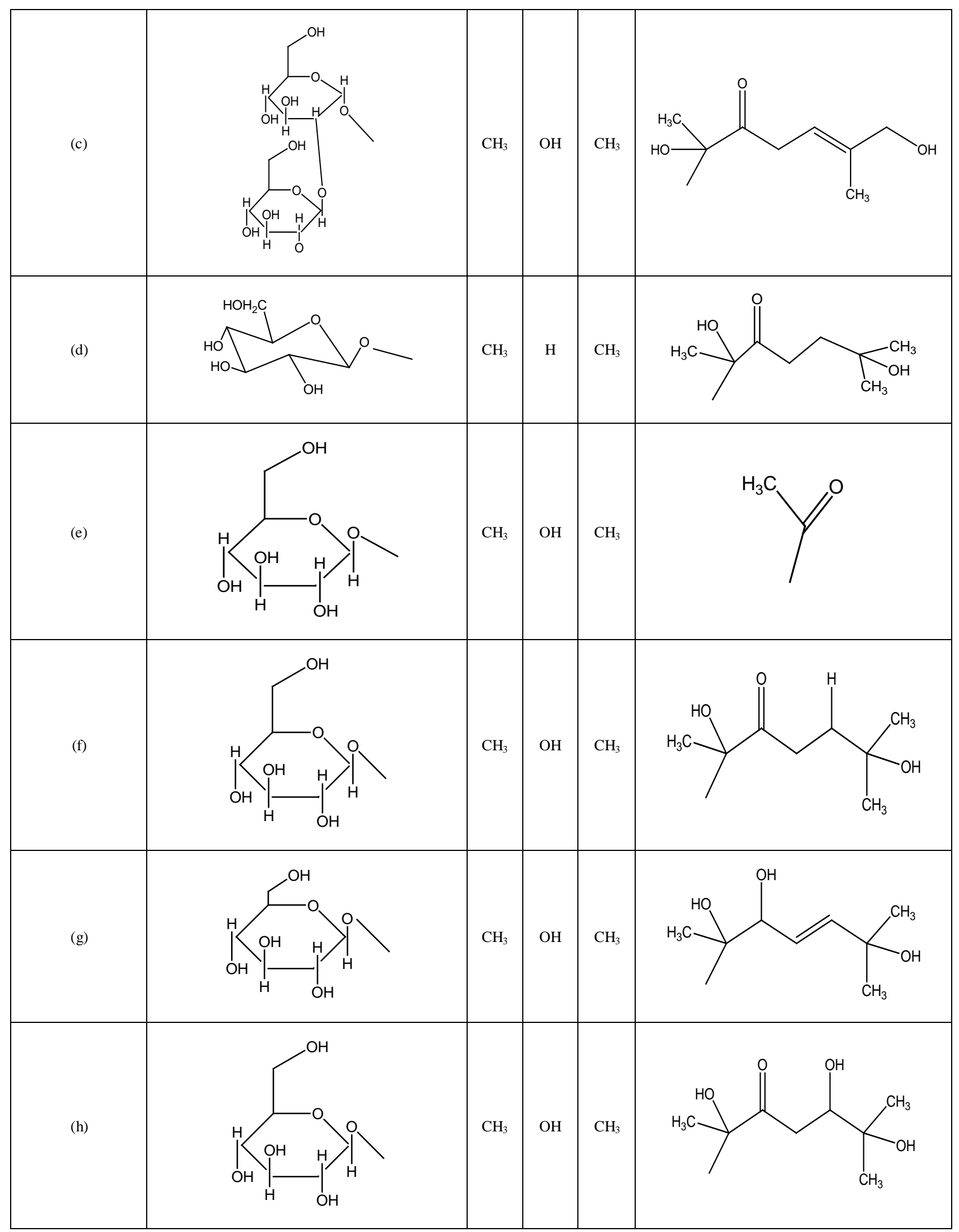



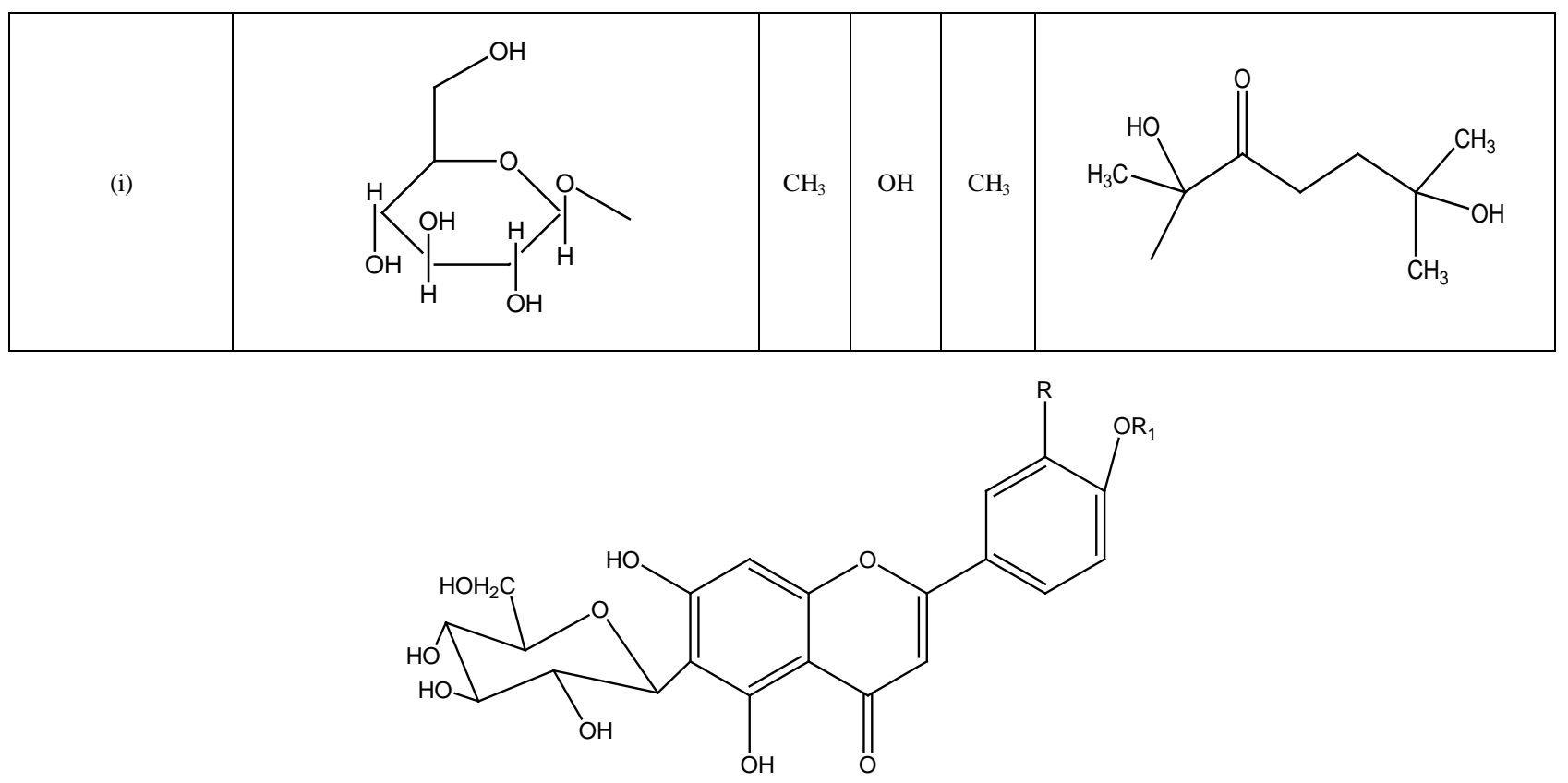

\begin{tabular}{|c|c|c|}
\hline Compounds & $\mathrm{R}$ & $\mathrm{R}_{1}$ \\
\hline$(\mathrm{j})$ & $\mathrm{OCH}_{3}$ & $\mathrm{H}$ \\
\hline$(\mathrm{k})$ & $\mathrm{H}$ & $\mathrm{H}$ \\
\hline$(\mathrm{l})$ & $\mathrm{H}$ & glucosyl \\
\hline
\end{tabular}

Figure 1. Chemical structures of various phytoconstituents found in Citrullus colocynthis (L.)Schrad. (a-l): (a) Cucurbitacin E; (b) Colocynthoside A; (c) Colocynthoside B; (d) Cucurbitacin L 2-O- $\beta$-D glucopyranoside; (e) Hexanocucurbitacin I 2-O- $\beta$-D glucopyranoside; (f) Cucurbitacin K 2-O- $\beta$-D glucopyranoside; (g) Khekadaengoside E; (h) Cucurbitacin J 2-O- $\beta$-D glucopyranoside; (i) Cucurbitacin I 2-O- $\beta$-D glucopyranoside; (j) Isoorientin 30-O-methyl ether ; (k) Isovitexin; (l) Isosaponarin

\section{Biological Activities}

Citrullus colocynthis (L.)Schrad. has the conventional use in treatment for cancer, carcinoma, endothelioma, leukemia, tumors of the liver, spleen, and eye [17]. A decoction of the entire plant, made with the juice of fennel is said to help indurations of the liver. Roots may likewise be utilized as a laxative and for treatment of rheumatism, urinary diseases, jaundice and in snake poison [17]. Citrullus colocynthis (L.)Schrad. is broadly utilized as a part of society prescription for quite a long time and as a vitality source too such as oilseed and biofuel. The leaves are diuretic and utilized as a part of the treatment of jaundice and asthma. The root is used as a treatment measure during inflammation of the breasts, rheumatism, joint pains, and amenorrhea and is also used externally in uterine torments and ophthalmia [17]. The fruit is pungent, cooling laxative, antipyretic, anthelmintic and carminative. They are used in cancer, leucoderma, ulcers, asthma, bronchitis, urinary discharge, enlargement of spleen, tuberculosis glands of the neck, dyspepsia, constipation, anemia's and throat diseases while fruit pulp acts as antiepileptic, purgative, diuretic and used against gonorrhea[17].The biological role of Citrullus colocynthis (L.) Schrad. has been attributed in Table No. 2.

\subsection{Antioxidant Activity}

In experimental studies on fruits of Citrullus colocynthis the total phenolic content, was found to be $0.74 \%$ of gallic acid equivalents of phenolic compounds and the total flavonoid content was $0.13 \%$ of catechin equivalent of fresh mass of C. colocynthis fruit extract. The free radical scavenging effect of fruit extract of this plant on the 2,2-diphenyl-1-picrylhydrazyl radical was found to be $88.0 \pm 2.7 \%(\mathrm{p}<0.005)$, at concentration of $2500 \mathrm{mgmL}^{-1}$ while scavenging effects of ascorbic acid, BHA and $\alpha$-tocopherol were found to be $50 \mathrm{mgmL}^{-1}$ of $89.5 \pm 1.1$, $83.2 \pm 1.1$ and $67.5 \pm 0.8 \%(p<0.05)$ respectively [18].

\subsection{Antihyperlipidemic Effect}

Citrullus colocynthis pulp and the seeds showed significant antihyperlipidemic results on New Zealand rabbits. The hypercholesterolemic control rabbits remained hypercholesterolemic throughout the experimental time but serum cholesterol and triglyceride in the groups administered with both seeds and pulps extracts of C. colocynthis were reduced $(\mathrm{p}<0.05)$. The reduction of LDL-C in the groups receiving the pulp extracts and 100 $\mathrm{mg} / \mathrm{kg}$ seed extract were significant $(\mathrm{p}<0.05)$. The impact of $C$. colocynthis on the blood lipid profile in rabbits might 
be because of high measures of saponins in C. colocynthis which diminished cholesterol levels by lessening the ingestion of cholesterol, expanding the repulse of feces estriol and looseness of the bowels because of expanded peristalsis [19].

\subsection{Antifertility Effects}

In this study, $50 \%$ ethanol extract of Citrullus colocynthis (L.) Schrad. administered orally to male albino rats for evaluation of antifertility effects. Prominently reduced cauda epididymis sperm density and motility, a number of pups, fertility, and circulatory levels of testosterone were seen in all treatment groups. The weights of testes, epididymis, seminal vesicle and prostate were significantly reduced in groups receiving $100 \mathrm{mg} / \mathrm{kg} /$ day C. colocynthis extract for periods of 20,40, and 60 days, respectively. The concentration of testicular cholesterol significantly increased, and sialic acid, protein, and alkaline phosphatase concentrations diminished. The histological analysis of the testis showed degenerative modifications in the seminiferous cells, cytolysis, and the lumen filled with eosinophilic substance. Hence 50\% ethanol extract of $C$. colocynthis fruit actuated reversible antifertility activity in male rats because of antiandrogenic nature [20].

\subsection{Antiulcer Activity}

Anti-ulcer activity of Citrullus colocynthis fruits showed positive results against pylorus ligation induced ulcers in male Wistar rats. Aqueous and ethanolic extracts of Citrullus colocynthis fruits administered at doses of 200 $\mathrm{mg} / \mathrm{kg}$ and $400 \mathrm{mg} / \mathrm{kg}$ evaluated parameter like- $\mathrm{pH}$, gastric volume, free acidity, total acidity, the percentage inhibition of ulceration and ulcer index. Ethanolic and aqueous extracts at $400 \mathrm{mg} / \mathrm{kg}$ indicated anoteworthy $(\mathrm{p}<0.001)$ decline in the total acidity, free acidity, and gastric volume. It showed also significant $(\mathrm{P}<0.001)$ decrease in ulcer score index and a number of ulcers in pylorus ligation ulceration model [21].

\subsection{Anticonvulsant Activity}

In the present study, the anticonvulsant activity of hydroalcoholic extract of Citrullus colocynthis Fruit involves the significant role of benzodiazepine and opioid receptors. Citrullus colocynthis pulp extract demonstrated a measurable significant reduction in the convulsions and increase in latency period of convulsions instigated by pentylenetetrazole in mice. Extract with doses 25 and 50 $\mathrm{mg} / \mathrm{kg}$ prolonged the onset of seizures and decreased the duration compared with control group. Anticonvulsive effect increased dose-dependently with following doses 10 , 25 , and $50 \mathrm{mg} / \mathrm{kg}$. The primary activity of the pentylenetetrazole-instigated seizure is decreasing $\mathrm{Y}$-aminobutyric acid level in the cerebral cortex region [22].

\subsection{Antimicrobial Effect}

Antimicrobial activity of the leaf extract of Citrullus colocynthis was carried out using agar disc diffusion technique against sixteen bacteria and six fungal strains. Phytochemical analysis showed the presence of active constituents like phenols, tannins, and flavonoids. Antimicrobial activity of extracts was compared with the standard Gentamicin (10 $\mu$ g/disc) \& piperacillin $(100 \mu \mathrm{g} / \mathrm{disc})$. Aqueous extract of the Citrullus colocynthis showed high antibacterial action against Staphylococcus aureus and E. coli and less impact against Klebsiella pneumoniae and Bacillus subtilis but, methanolic extracts showed better antibacterial action against Bacillus subtilis, Streptococcus pyogenes, Salmonella typhi [23].

\subsection{Antifungal Activity}

The present study evaluated the antifungal activity of hydroalcoholic extracts of Citrullus colocynthis fruit against different Candida and Aspergillus strains. Anti-Aspergillus and Anti-Candidal actions were studied by disc diffusion and broth macrodilution methods. All tested parasitic strains indicated sensitivity to the extract. The minimum fungicidal concentration and minimal inhibitory concentration values ranged from 3.125 to 25 $\mathrm{mg} / \mathrm{ml}$ and 1.56 to $12.5 \mathrm{mg} / \mathrm{ml}$ respectively. The high antifungal action was seen against $A$. niger and $A$. fumigatus as compared to the strains of $C$. krusei and $C$. guilliermondii [24].

\subsection{Antibacterial Activity}

In this experiment, the antibacterial effect of Citrullus colocynthis fruits and leaves extracts against a standard (ATCC 25923) and isolated strains of Staphylococcus aureus from novobiocin treatment patients was assessed utilizing disc diffusion method. Phytochemistry of this plant showed constituents like tannins, saponins, alkaloids, flavonoids, and glycosides. The ethanolic extract showed a significant inhibitory activity against $\mathrm{S}$. aureus as compared to aqueous extract in a dose-dependent manner [25].

\subsection{Insecticidal Effect}

Insecticidal effect of Cucurbitacin E Glycoside (2-O- $\beta$-D-glucopyranosyl cucurbitacin E) isolated from Citrullus colocynthis was tested against Aphis craccivora. Different extracts of Citrullus colocynthis fruits (methylene chloride, n-hexane, ethanol, and chloroform) 
against $\mathrm{A}$. craccivora were studied in this experiment. The highest insecticidal effect (LC 11003 ppm) was obtained from the ethanol extract [15].

\subsection{Antibacterial and Anticandidal Activity}

In vitro antibacterial and anticandidal activity of aqueous and diluted acetone extracts of Citrullus colocynthis Schrad. MIC and MBC/MFC were assessed in plant roots, stems, leaves and three maturation stages of its fruit and seeds against gram-negative and gram-positive bacteria like Escherichia coli, Pseudomonas aeruginosa, Staphylococcus aureus and Enterococcus faecalis and Candida spp. like candida glabrata, candida albicans, Candida parapsilosis and candida kreusei. The most elevated minimum inhibitory concentration (MICs) and minimum bactericidal concentration (MBCs) were obtained from the fruit aqueous extracts (MIC $0.20 \mathrm{mg} / \mathrm{ml}$ against Escherichia coli and Pseudomonas aeruginosa and $0.10 \mathrm{mg} / \mathrm{ml}$ against Candida albicans and Candida glabrata) and obtained lowest activity from the plant root extracts [26].

\subsection{Hypoglycemic Activity}

The hypoglycemic effect of root of C. colocynthis on the biochemical parameters of normal and alloxan-induced diabetic rats was studied in this experiment. Aqueous extract of roots of Citrullus colocynthis demonstrated critical decrease in glucose level (58.70\%) when contrasted with chloroform (34.72\%) and ethanol extracts (36.60\%) $(\mathrm{p}<0.01)$. The aqueous extracts indicated positive change in parameters like serum creatinine, body weight, serum protein and urea as well as lipid profile and furthermore reestablished the serum level of conjugated bilirubin, bilirubin total, serum glutamate pyruvate transaminase (SGPT), serum glutamate oxaloacetate transaminase (SGOT), and alkaline phosphatase (ALP) [27].

\subsection{Antihyperglycaemic Effect}

Antihyperglycaemic effects of the alkaloidal, glycosidic, saponin and aqueous extracts of the rind of Citrullus colocynthis on the plasma glucose levels were studied in normal rabbits and the action of saponin extract on the fasting blood sugar levels were studied in alloxan-induced diabetic rabbits. Oral dosage of aqueous extract of Citrullus colocynthis $(300 \mathrm{mg} / \mathrm{kg})$ in normal rabbits produced noteworthy decrease in plasma glucose after $1 \mathrm{~h}$ and was exceptionally huge after 2, 3 and $6 \mathrm{~h}$. The action was more articulated with saponin extract which decreased the glucose levels (fasting) after 1 and $2 \mathrm{~h}$ and significantly $(\mathrm{p}<0.001)$ after 3 and $6 \mathrm{~h}$ [28].

\subsection{Antidiabetic Activity}

Antidiabetic action of petroleum ether fruits extract of Citrullus colocynthis against Streptozotocin initiated hyperglycemic rats was assessed after oral administration of two distinct doses (300 and $500 \mathrm{mg} / \mathrm{kg}$ ) of Citrullus colocynthis. Phytochemical investigations revealed following chemical constituents like alkaloids, terpenes, saponins and glycosides. Administration of petroleum ether extract of Citrullus colocynthis fundamentally enhanced body weight of diabetic rats in a dose and time-dependent manner. Citrullus colocynthis showed antidiabetic action through stimulation of $\beta$-cells of islets of Langerhans by releasing more insulin and this effect were brought about by constituents like glycosides, saponins, flavonoids [29].

\subsection{Analgesic Activity}

In the following experiment, immature fruit aqueous extracts of Citrullus colocynthis obtained from various populations of Tunisia was evaluated for analgesic activity. The alkaloid level differs from the Citrullus colocynthis population. All extracts displayed analgesic activity at different doses without inducing acute toxicity. Studies also reveal that steroids and iridoids which are present in this plant may contribute to a better performance. The immature fruits from Medenine region showed highest analgesic activity. The lowest activity was seen for Hammamet region fruits (90.86\%). This immature fruit exhibited a high activity at very low aqueous extract doses $(0.1 \mathrm{mg} / \mathrm{Kg}$ and $2 \mathrm{mg} / \mathrm{Kg}$ ) [30]. 
Table 2. Representation of biological activities shown by various plant parts of Citrulluscolocynthis (L.)Schrad. and phytoconstituents responsible for biological activity

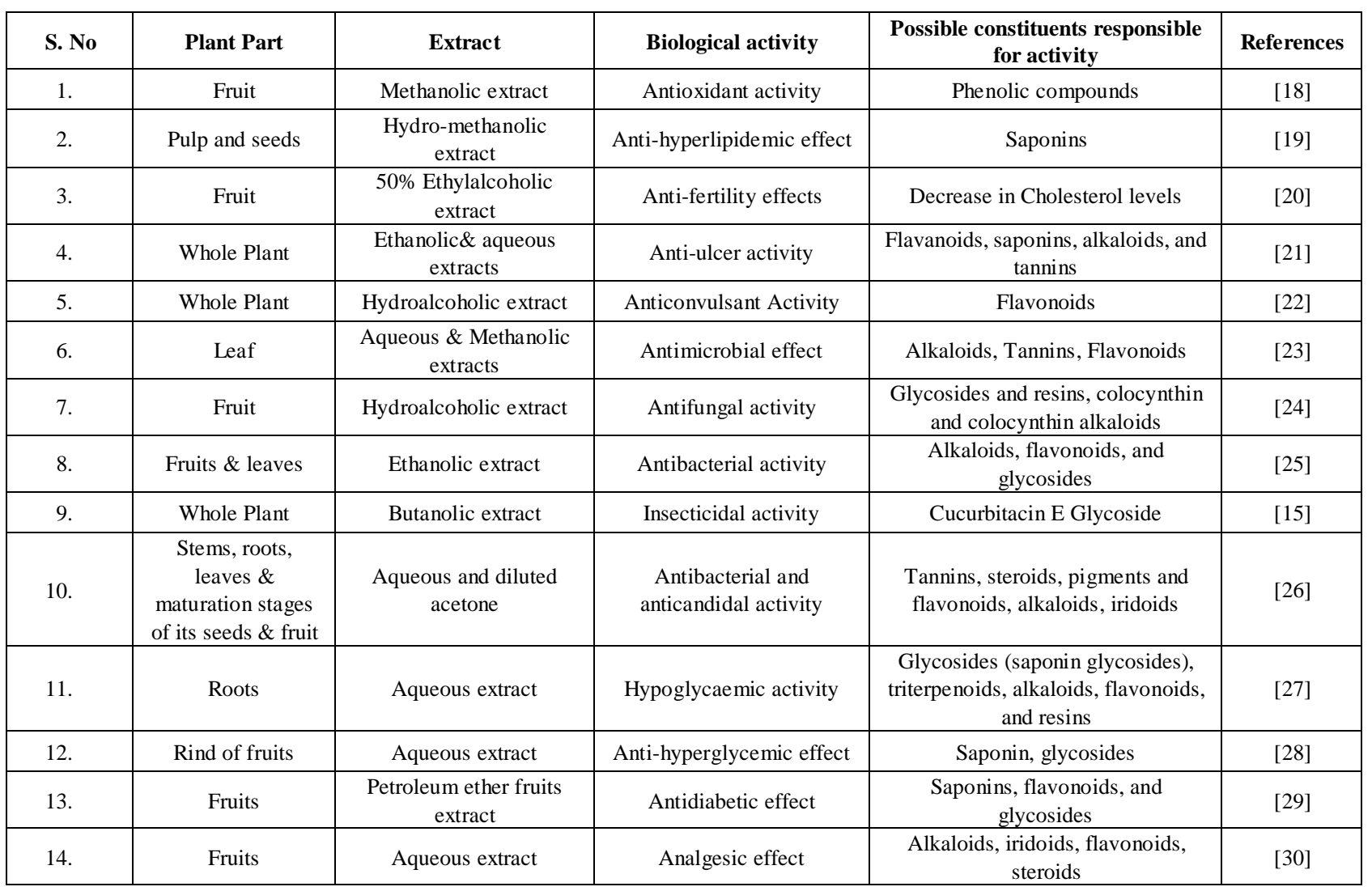

\section{Discussions}

Traditionally Citrullus colocynthis (L.) Schrad. has been utilized as a plant of medicinal significance at various nativities in different parts of the world. Experimental studies have proven the presence of various phytochemical compounds in the whole of the plant including fruits, seeds, root, and shoot. With the literature survey done in this review cucurbitacins form the most abundant compounds found in this plant species. Some other constituents like phenolic compounds, saponins, flavonoids, alkaloids, tannins, glycosides, triterpenoids, resins, and steroids are also present in this plant. Their structures have also been elucidated in different experimental studies as mentioned in the present review. As far as the pharmacological studies are concerned, till now only the above-mentioned activities (Table 2) have been evaluated. These include antioxidant activity, anti-hyperlipidemic effect, anti-fertility effects, anti-ulcer activity, anticonvulsant activity, antimicrobial effect, antifungal activity, antibacterial activity, insecticidal activity, anticandidal activity, antidiabetic effect, and analgesic effect. Still, a lot of research is needed on Citrullus colocynthis (L.) Schrad. regarding phytochemistry and biological evaluations of certain activities which have been mentioned in the literature and also being practiced by the traditional people.

\section{Conclusions}

In the present study, the authors reported the phytochemical constituents and biological activities of the Citrullus colocynthis (L.) Schrad. Several plants parts like leaf, stem, roots, fruits, and seeds have been studied extensively by eminent scientists and researchers. Moreover, fruit holds much biological and chemical significance as far as the above study is concerned. Biological activities showed by different parts of this plant display a multidisciplinary usage of this plant in treating several diseases. Although a number of compounds and many pharmacological activities have been elucidated in this plant species still more research is needed to be done as many traditional uses been reported so far are required to be authenticated by research.

\section{Acknowledgements}

We are very grateful to Prof. Kailash Agrawal \& Dr. Manju Sharma of Department of Botany, the University of Rajasthan for their appropriate and constructive suggestions as well as Dr. Ramji Gupta and Dr. Amit Singh of R.V. Northland Institute for their unduly support. 


\section{Conflict of Interest}

Authors declare that there are no conflicts of interest.

\section{REFERENCES}

[1] H. Riaz, S. Ali, S. Chatha, A. I. Hussain, S. Anwer, S. M. Hussain, and K. Zafar, "Physico-chemical characterization of bitter apple (Citrullus colosynthis ) seed oil and seed residue,” Int. J. Biosci., vol. 6, no. 1, pp. 283-292, 2015.

[2] A. I. Hussain, H. A. Rathore, M. Z. A. Sattar, S. A. S. Chatha, S. D. Sarker, and A. H. Gilani, "Citrullus colocynthis (L.) Schrad. (L.) Schrad (bitter apple fruit): A review of its phytochemistry, pharmacology, traditional uses, and nutritional potential,” J. Ethnopharmacol., vol. 155, no. 1, pp. 54-66, 2014.

[3] D. Schafferman, A. Beharav, E. Shabelsky, and Z. Yaniv, "Evaluation of Citrullus colocynthis (L.) Schrad., a desert plant native in Israel, as a potential source of edible oil," $J$. Arid Environ., vol. 40, no. 4, pp. 431-439, 1998.

[4] B. Upadhyay, K. P. Singh, and A. Kumar, "Ethno-veterinary uses and informants consensus factor of medicinal plants of Sariska region, Rajasthan, India,” J. Ethnopharmacol., vol. 133, no. 1, pp. 14-25, 2011.

[5] H. M. H. Salama, "Alkaloids and flavonoids from the air-dried aerial parts of Citrullus colocynthis (L.) Schrad." Journal of Medicinal Plants Research, vol. 6, no. 38, pp. 5150-5155, 2012.

[6] K. K. and P. S. Jamuna S, "Phytochemical and pharmacological properties of certain medicinally important species of Cucurbitaceae family - a review," J. Res. Biol., vol. 5, no. 6, pp. 1835-1849, 2015.

[7] R. Chawech, R. Jarraya, C. Girardi, M. Vansteelandt, G. Marti, I. Nasri, C. Racaud-Sultan, and N. Fabre, "Cucurbitacins from the Leaves of Citrullus colocynthis (L.) Schrad. (L.) Schrad,” Molecules, vol. 20, no. 10, pp. 1800118015, 2015.

[8] P. Taylor, D. Nayab, D. Ali, N. Arshad, A. Malik, I. Choudhary, and Z. Ahmed, "Cucurbitacin glucosides from Citrullus colocynthis (L.) Schrad. ,” Nat. Prod. Res., vol. 20, no. 5, pp. 409-413, 2006.

[9] J. Jeon and H. Lee, "Biofunctional Constituent Isolated from Citrullus colocynthis (L.) Schrad. Fruits and Structure Activity Relationships of Its Analogues Show Acaricidal and Insecticidal Efficacy,” J Agric. Food Chem., vol.62, no. 34, pp. 8663-8667, 2014.

[10] M. C. Meena and V. Patni, "Isolation and Identification of Flavonoid 'Quercetin' from Citrullus colocynthis (L.) Schrad.(Linn.) Schrad.,” Assin J Exp Sci., vol. 22, no. 1,pp. 137-142, 2008.

[11] A. Delazar, S. Gibbons, A. L. I. R. Kosari, M. Modarresi, L. Nahar, D. Satyajit, C. Londonderry, and N. Ireland, "Flavone c-glycosides and cucurbitacin glycosides from Citrullus colocynthis (L.) Schrad. Faculty of Pharmacy and Drug Applied Research Center, Tabriz University of
Medical of Biomedical Sciences, University of Ulster at Coleraine, Cromore Road, Coleraine,” vol. 14, no. 3, pp. 109-114, 2006.

[12] N. A. R. Hatam, D. A. Whiting, and N. J. Yousf, "Cucurbitacin glycosides from Citrullus colocynthis," Phytochemistry., vol. 28, no.4, pp. 1268-1271, 1989.

[13] D. Lavie and D. Will, "Constituents of Citrullus colocynthis schrad.,” Phytochemistry., vol.3, pp.51-56, 1964.

[14] S. E. N. Ayyad, A. Abdel-Lateff, W. M. Alarif, F. R. Patacchioli, F. A. Badria, and S. T. Ezmirly, "In vitro and in vivo study of cucurbitacins-type triterpene glucoside from Citrullus colocynthis (L.) Schrad. growing in Saudi Arabia against hepatocellular carcinoma,” Environ. Toxicol. Pharmacol., vol. 33, no. 2, pp. 245-251, 2012.

[15] A. Z. A. Torkey, H.M. Azeiz, "Insecticidal Effect of Cucurbitacin E Glycoside Isolated from Citrullus colocynthis (L.) Schrad. Against," Australian Journal of Basic and Applied Sciences., vol. 3(4), no. October 2009, pp. 4060-4066, 2009.

[16] C. Seger, S. Sturm, M. Mair, E. P. Ellmerer, and H. Stuppner, "Spectral Assignments and Reference Data $1 \mathrm{H}$ cucurbitacin derivatives from Citrullus,” Magn. Reson. Chem., vol. 43, no. March, pp. 489-491, 2005.

[17] C. Uma and K. G. Sekar, "Phytochemical analysis of a folklore medicinal plant Citrullus colocynthis (L.) Schrad L (bitter apple)". Journal of Pharmacognosy and Phytochemistry., vol. 2, no. 6, pp. 195-202, 2014.

[18] S. Kumar, D. Kumar, Manjusha, K. Saroha, N. Singh, and B. Vashishta, "Antioxidant and free radical scavenging potential of Citrullus colocynthis (L.) Schrad. methanolic fruit extract.," Acta Pharm., vol. 58, no. 2, pp. 215-20, 2008.

[19] M. Zamani, A. O. Rahimi, R. Mahdavi, M. Nikbakhsh, and V. Morteza, “Artigo,” Rev. Bras. Farmacogn. Brazilian J. Pharmacogn., vol. 17, no. 4, pp. 492-496, 2007.

[20] M. Chaturvedi, P. C. Mali, and A. S. Ansari, "Induction of reversible antifertility with a crude ethanol extract of Citrullus colocynthis (L.) Schrad fruit in male rats," Pharmacology, vol 68, no. 1, pp 38-48, 2003.

[21] V. P. Reddy, "Evaluation of anti-ulcer activity of Citrulluscolocynthis (L.) Schrad.fruit against pylorus ligation induced ulcers in male Wistar rats," Int J Pharm Pharm Sci., vol. 4, no. 2, pp. 2-7, 2012.

[22] S. Mehrzadi, A. Shojaii, S. A. Pur, and M. Motevalian, "Anticonvulsant Activity of Hydroalcoholic Extract of Citrullus colocynthis (L.) Schrad. Fruit: Involvement of Benzodiazepine and Opioid Receptors,” J Evid Based Complementary Altern Med., vol. 21, no. 4, pp. 31-35, 2016.

[23] K. Gurudeeban, S., Rajamanickam, E., Ramanathan, T and Satyavani, "Antimicrobial activity of Citrullus colocynthis (L.) Schrad.in the gulf of mannar,” Int. J. Curr. Res., vol. 2, no. January 2016, pp. 78-81, 2010.

[24] S. Eidi, H. G. Azadi, N. Rahbar, and H. R. Mehmannavaz, "Evaluation of antifungal activity of hydroalcoholic extracts of Citrullus colocynthis (L.) Schrad. fruit,” J. Herb. Med., vol. 5, no. 1, pp. 36-40, 2015.

[25] S. Najafi, N. Sanadgol, B. S. Nejad, M. A. Beiragi, and E. Sanadgol, "Phytochemical screening and antibacterial 
activity of Citrullus colocynthis (L.) Schrad. (Linn.) schrad against Staphylococcus aureus,” J. Med. Plants Res., vol. 4, no. 22, pp. 2321-2325, 2010.

[26] B. Marzouk, Z. Marzouk, R. Décor, H. Edziri, E. Haloui, N. Fenina, and M. Aouni, "Antibacterial and anticandidal screening of Tunisian Citrullus colocynthis (L.) Schrad from Medenine,” J. Ethnopharmacol. J., vol. 125, pp. 344-349, 2009.

[27] G. R. Agarwal, V. Sharma, A. Kumar, A. Upadhyay, G. Singh, "Hypoglycemic effects of Citrullus colocynthis (L.) Schrad. roots,” Acta Polaniae Pharm. Res., vol. 69(1), no. January, pp. 75-79, 2012.

[28] I. A. Abdel-hassan and J. A. Abdel-barry, “The hypoglycaemic and antihyperglycaemic effect of Citrullus colocynthis (L.) Schrad. fruit aqueous extract in normal and alloxan diabetic rabbits,” J. Ethnopharmacol., vol. 71, no. 2000, pp. 325-330, 2000.

[29] P. N. N. Jayaraman R, Arihara Shivkumar, Anitha T, Joshi Vishal D, “Antidiabetic effect of petroleum ether extract of Citrullus colocynthis (L.) Schrad. fruits against streptozotocin-induced hyperglycemic rats,” Rom. J. Biol.-Plant Biol., vol. 54, pp. 127-134, 2009.

[30] B. Marzouk, E. Haloui, N. Fenina, M. Aouni, and Z. Marzouk, "Comparative evaluation of the analgesic activity of several populations of Tunisian Citrullus colocynthis (L.) Schrad. immature fruits," Journal of Applied Pharmaceutical Science., vol. 3, no. 5, pp. 22-26, 2013. 